5-8-2011

\title{
One Right Answer?: The Meta Edition
}

Dan Priel

Osgoode Hall Law School of York University, dpriel@osgoode.yorku.ca

Follow this and additional works at: http://digitalcommons.osgoode.yorku.ca/all_papers

Part of the Law Commons

\section{Repository Citation}

Priel, Dan, "One Right Answer?: The Meta Edition" (2011). All Papers. Paper 257.

http://digitalcommons.osgoode.yorku.ca/all_papers/257

This Working Paper is brought to you for free and open access by the Research Papers, Working Papers, Conference Papers at Osgoode Digital

Commons. It has been accepted for inclusion in All Papers by an authorized administrator of Osgoode Digital Commons. 


\title{
One Right Answer?: The Meta Edition
}

\author{
Dan Priel \\ Sir James Stephen is not the only writer whose attempts to \\ analyze legal ideas have been confused by striving for a \\ useless quintessence of all systems, instead of an accurate \\ anatomy of one. ${ }^{1}$
}

\section{Introduction}

Let me start with two quotes that look, and indeed are, very far from discussions of the nature of law:

[The members of Obama's economic team's] faith in the power of analysis remained unshaken. Obama believed ... that knotty public policy problems had right answers and wrong answers and that if you put enough smart people on the problem, you could usually get to the right answer."

This disconnection from the world was the malign consequence of the American love of expertise, which, with the help of citadels of the meritocracy, had moved from a mere culture to something approaching a cult. Obama was skeptical of cant but still in thrall to the idea that with enough analysis, there was a "right answer" to everything. ${ }^{3}$

Could the "American love of expertise" and the belief that "with enough analysis, there was a 'right answer' to everything" have anything to do with debates in jurisprudence? Is it even appropriate to suggest that the conceptual debates of the nature of law, debates that purport to take place above the concerns of the here and now have anything to do with the everyday affairs that make up real-life politics? In this essay I will suggest that the answer may be, "yes, they do."

The immediate instigation for this discussion is, of course, Ronald Dworkin's "right answer thesis."4 For some time during the late 1970s and early 1980s Dworkin's claim that there are uniquely right answers to virtually all legal questions was the subject of heated debate. But as debates of this sort are prone to, it eventually ran out of steam,

* Visiting Professor, Osgoode Hall Law School (2010-11); Assistant Professor, University of Warwick School of Law. Email: dpriel@osgoode.yorku.ca. This essay will be presented at the Nature of Law Conference at McMaster University, May 2011. This is work in progress; comments are welcome.

${ }^{1}$ O.W. Holmes, “The Path of the Law," 10 Harvard Law Review 457, 475 (1897).

${ }^{2}$ Jonathan Alter, The Promise: President Obama, Year One (New York: Simon And Schuster, 2009) 62.

${ }^{3}$ Ibid. at 340 .

${ }^{4}$ See, among other places, Ronald Dworkin, A Matter of Principle (Cambridge: Harvard University Press, 1985) ch. 5 . 
though neither side convinced the other of the error of its ways. It may therefore seem a bit odd to return to this topic now. If I do so, it is because I wish to examine it from an angle that I think it has not yet been looked at, and which I think is relevant to some debates that are very much alive these days. More specifically, I will argue that there is something about the right answer thesis that fits a certain view prevalent in American political culture about politics and (consequently) about the relationship between law and politics, and that this view is quite different from the British mainstream view about law and politics. The more general and more important goal of this essay is to challenge the underlying idea of the search for the nature of law, at least so long as it is understood as a conceptual inquiry that purports to tell something about law outside the different political and cultural environments in which different legal systems operate. Somewhat surprisingly, many of the very same legal theorists who have argued vigorously against the view that there is a single right answer to legal questions accepted (or actually, assumed) such a view is correct at the meta-level question of the nature of law. I think this is assumption is mistaken, and my essay is an attempt to explain why.

\section{Changing Places}

Returning from his year in the United States Hart recorded his impressions of the United States for the BBC. These were then published in the BBC's magazine The Listener. This short piece, "A View of America," reflects Hart's astonishment with what he saw in the United States. Coming from a country that was still slowly recovering from two wars that had left it practically bankrupt, the essay tells us about the tall buildings, the wide roads, the big cars, and the resourceful universities. The essay also contains some pertinent comments about American politics and how different they were from what he was used to at home. One thing that particularly impressed Hart was

the passion inspiring so many whom you meet for the moral issue. Argument soon breaks through to what is believed, apparently, to be at the root of every problem-a moral problem. And, more widespread than I could have believed, was the conviction that just as there lurks at the bottom of problem a moral question, so there must somewhere be an answer, an answer perhaps for the sage - and he may be in the university-to provide. ${ }^{5}$

This is a fairly neat summary of Dworkin's right answer thesis. It would not be so surprising to those who know something about the debates that would come to dominate legal philosophy in the following decades had it not been for the fact that Hart wrote this

\footnotetext{
${ }^{5}$ H.L.A. Hart, “A View of America," 59 Listener 89, 89 (1958). Surprisingly, even though Nicola Lacey discusses this little essay at some length in A Life of H.L.A. Hart: The Nightmare and the Noble Dream (Oxford: Oxford University Press, 2006) 193-96, she does not mention this remarkable passage.
} 
some five years before Ronald Dworkin published his first article. And yet Hart was not talking here not about American law but on American politics. This, as I will try to show below, is not a coincidence.

Unlike Hart who only made a few visits to the United States, Dworkin lived and taught in Britain for many years. ${ }^{6}$ But he always remained, I think, a relative outsider to the legal and political culture in Britain. He has been, for example, a frequent commentator on American constitutional cases in the New York Review of Books, but to the best of my knowledge has never written a similar essay on a British case. He has seen enough, however, to note the differences between in the political cultures of the two countries, writing once that "public debate in the United States is dominated, to a degree British commentators find surprising, by discussion of what rights people have." Dworkin's most detailed discussion of British law and politics is found in a relatively unknown pamphlet (or is it a book?) entitled A Bill of Rights for Britain. Summarized in a sentence, in this essay Dworkin recommends that Britain's law and politics be turned into something more-or-less like their American counterparts. In order for people to "participate in government ... constantly through informed and free debate ... Parliament must be constrained in certain ways in order that democracy be genuine rather than a sham." ${ }^{\text {S }}$ Such a change, he suggested might make "[l]aw and lawyers ... begin to play a different, more valuable role in [British] society than they now even aim to have." It would encourage courts to "think more in terms of principle and less in terms of narrow precedent." Such a change would help foster "a legal profession that could be the conscience, not just the servant, of government and industry." In short, Dworkin recognized that there are fundamental differences in the political culture of Britain and the United States, and that those had fundamental implications for the way lawyers perceived their role in society.

${ }^{6}$ I used "Britain" throughout this essay, despite the fact that the term may be deemed misleading, since for the most part I am talking here more about England. Precision had to be given up here for simplifying the discussion. Those troubled by this usage are entitled to mentally read "England" and "English" wherever I write "Britain" and "British." Though less loaded, "American law" is not free from difficulties either. Again, I stuck with this phrase aware of its imprecision. I believe that in neither case does my choice of word get in the way of my argument.

${ }^{7}$ Dworkin, supra note 4, at 31-32.

${ }^{8}$ Ronald Dworkin, A Bill of Rights for Britain (London: Chatto \& Windus, 1990) 33 (emphasis in original). Incidentally, these days Dworkin has somewhat softened his views on judicial review. See Ronald Dworkin, Justice for Hedgehogs (Cambridge: Harvard University Press, 2011) 398-99.

${ }^{9}$ Ibid. at 23. 


\section{Two Ways to the Rule of Law}

I want to suggest that these reflections on the political differences between the United States and Britain that both Hart and Dworkin noticed are relevant to legal philosophy. At this stage I will phrase my argument as weakly as I can: since law interacts with politics, the fact that different political communities have different conceptions of politics is likely to have an impact on their conception of law. I will examine this argument in the context of one aspect of the rule of law, namely that of the requirement that the content of the law is not affected by the identity of the person charged with saying what it is. This sense is sometimes captured by the slogan "the rule of law and not of men," and is associated with one sense of objectivity, that of non-perspectival constancy or invariance. Put in everyday terms, it is the demand that if different people are asked to state what the law requires on a particular question, will offer the same answer. (This, of course, is not the only sense of the rule of law.)

When legal philosophers address the question they usually do so by trying to connect debates about objectivity in law to the subtle and sophisticated discussions of objectivity among philosophers where the topic has been front and center of virtually every field of philosophy. These jurisprudential contributions provided important correctives to those who considered any claims about the possibility of objective knowledge (in law, in general) as naïve or even reactionary. However, in focusing on the question of objectivity in this epistemological and metaphysical context they shifted attention away from the issues that lawyers are mostly interested in. For lawyers do not usually wonder about whether Truth exists, or what reality consists of. They are, however, intensely interested, practically interested, in potential problems that could undermine objectivity in the particular sense I associated with the rule of law. The worry is that people's personal (possibly unconscious) prejudices, their political opinions, or cultural background, will affect their determination of the law thus undermining the possibility of invariance among different people. The unique problem of objectivity in law can thus be summarized as follows: (1) law should be (in the specific sense explained above) objective; (2) law (in modern society) primarily deals with questions that deal, directly or indirectly, with the relationship between individual and the state; (3) questions of this sort are often politically controversial, and therefore (4) law's objectivity is in danger. What emerges from these three propositions is that, especially in the modern welfare state, there is tension between the aims for objectivity in the law and its subject-matter.

Setting up the problem at this level of abstraction is fairly easy. What makes finding a solution to it difficult is that the issue is not simply one of finding the optimal design of legal institutions to minimize a clearly set problem. Part of the difficulty arises from the fact that the understanding of the problem itself changes in different political 
environments, and therefore there are several possible ways of understanding what would count as a successful solution. One way of understanding my argument below is that we can identify a difference in the mainstream legal academic positions in Britain and the United States not simply about the means of achieving the optimal level of separating between law and politics, but rather on what that level should be. To complete my argument about the error in the way debates about the nature of law are currently conducted I will need to show, first, that determining this matter is relevant to debates about the nature of law, and second, that these different answers to this matter, and as a result different understandings of the nature of law, are going to be given in different legal systems if their political cultures are different. I will make exactly this argument later on, but first I will specify in more detail the way the British and the American legal systems have responded to the problem of objectivity specified above.

\section{The British Response}

The traditional, and still typical, response in Britain to the potential challenge that politics poses to the rule of law is to insist on a categorical separation of law and politics. "The matter of legal science," wrote Pollock and Maitland, "is not an ideal result of ethical or political analysis; it is the actual result of facts of human nature and history." 10 This distinction is maintained through the more-or-less conscious adoption of various institutional means aimed at minimizing the potential infiltration of politics into the law, and no less importantly, of law into politics. Some of these means for achieving that are rather familiar, others perhaps less so. I mention a few of them here:

(1) The doctrine of Parliamentary supremacy. In the course of a discussion of the differences between the United States and Britain Hart wrote how the "defenders of the British government's policy had come to think not merely that Parliament had unlimited legislative powers as a matter of English constitutional law but that it was a general necessary and indeed self-evident truth that government by law could not be limited by law." 11 In presenting this view like that Hart wants to show that though the matter was thought to be conceptual, it was merely a reflection of a particular political choice, one that could be easily refuted by pointing, as Hart himself did in his critique of Austin, to

\footnotetext{
${ }^{10} 1$ Frederick Pollock \& Frederic William Maitland, The History of English Law before the Time of Edward I (Cambridge: Cambridge University Press, 1895) xxiii. Notice that this strict separation between between declaring law and changing it, and between (descriptive) jurisprudence and (normative) moral and political theory as the respective domains of inquiry for these questions, is also a linchpin of contemporary legal positivism. This is very clear in Joseph Raz, Ethics in the Public Domain (Oxford: Clarendon Press, rev. ed., 1995) 208, 209.

${ }^{11}$ H.L.A. Hart, "Bentham and the USA," 19 Journal of Law and Economics 547, 551 (1976).
} 
the United States as a counterexample. ${ }^{12}$ The truth, however, is that though there were some who sought to present the matter in this conceptual fashion, the opposition to legal limitations on Parliamentary power was normative. To its proponents Parliamentary sovereignty was a good idea. ${ }^{13}$ One good thing to come from Parliamentary sovereignty is a smaller likelihood that courts will be embroiled in political questions and in this way making sure the objectivity of law is not compromised.

(2) Judicial deference to government action. For a long time British law contained a kind of sneering attitude toward the (French, obviously) idea of administrative law. Dicey, still probably the most influential public lawyer in Britain today, almost a century after his death, doubted whether it was even appropriate to talk of British law containing anything that could properly be described as administrative law. ${ }^{14}$ British public servants could be liable in civil courts if their actions fell within the scope of private civil liability, but there was no place for any other rules beyond that. This approach has resulted in a judicial mindset that was described by one legal historian as one of "total deference to the executive." ${ }^{15}$ A wide doctrine of justiciability, an almost uninterrupted discretion to public authorities (under what British public lawyers call "Wednesbury unreasonableness"), ${ }^{16}$ and narrow scope for tort liability of public authorities, have all served to keep executive action relatively free from legal oversight. Of course, one can find examples of all that in other places as well, but in comparison to courts in other Western democracies, and more specifically in comparison with American courts, in much of the twentieth century British courts were remarkably timid. ${ }^{17}$

${ }^{12}$ H.L.A. Hart, The Concept of Law (Oxford: Clarendon Press, 2nd ed., 1994) 72-74. Many others have made this point against Austin before Hart. See, e.g., 2 James Bryce, Studies in the History of Jurisprudence (Oxford: Clarendon Press, 1901) 89-94; Henry Sidgwick, The Elements of Politics, (London: Macmillan, 2nd ed., 1897) 25-28.

13 For a summary of the overwhelmingly political arguments against such limitations, Jeffrey Goldsworthy, The Sovereignty of Parliament: History and Philosophy (Oxford: Oxford University Press, 2001) 233-34.

14 A.V. Dicey, Lectures Introductory to the Study of the Law of the Constitution (London: Macmillan, 1885) 215-16 ("the notion which lies at the bottom of the 'administrative law' known to foreign countries ... is utterly unknown to the law of England.").

${ }^{15}$ Robert Stevens, Law and Politics: The House of Lords as a Judicial Body, 1800-1976 (Chapel Hill: University of North Carolina Press, 1978) 320, also ibid. at 388-89 ("parliamentary sovereignty implied that there should be no serious judicial questioning not only of acts of Parliament, but of decisions of the Civil Service").

${ }^{16}$ So called after Associated Provincial Picture Houses v. Wednesbury Corporation, [1947] 1 K.B. 223 (C.A.).

${ }^{17}$ See generally, Robert Stevens, The English Judges: Their Role in the Changing Constitution (rev. ed., 2005) 31-46. 
(3) Focus on doctrine in legal education and legal scholarship. What does it mean to be a good lawyer? In the best known British law schools this still means, to a degree that would astound American law professors, mastering a vast amount of legal rules by reading a breathtaking number of cases, while giving relatively little consideration to question of social policy. In a kind of feedback loop mechanism doctrinal legal education is both a product of and a mechanism for maintaining the separation of law from politics. This is not merely a matter of legal education: doctrinal, "black-letter" scholarship-from the case note to the comprehensive treatise-is a genre still accorded great respect among British academics. As a result even what counts as "theoretical" work in Britain is much more geared towards "internal" conceptual or taxonomical work than in the United States. This kind of work both by what is found in it, but also but what is not, helps to foster the view that law and politics are separate domains. (The greater dominance of analytic jurisprudence in the very same law schools in which the doctrinal study of law is dominant is, I think, part of the same phenomenon.)

\section{The American Response}

The American scene is different. It is already in the first half of the nineteenth century that Tocqueville famously wrote " $t$ ] here is hardly a political question in the United States which does not sooner or later turn into a judicial one." ${ }^{18}$ And this enchantment with law has the location for political battle has since intensified manifold.

One source of all these differences is the United States Constitution, understood primarily as a legal document that empowers courts to declare certain legislation unconstitutional. Another has been pointed out by Hart in the very same essay from which I quoted above:

For [the English], surely, liberty is this: that there is a circle round each man, inside which he can do as he please, and it is no concern of others; this is the liberty the Englishman has inside his house and garden and behind its hedges. I think that this as an ideal makes little appeal to an enormous number of Americans; I believe you can find what the American means by liberty by looking at the Constitution of an American State. In the State of Massachusetts the Constitution provides that any member of the public may introduce a measure into the Legislature and argue for it before committees. And it seems to me that this is what an American means by liberty; the right to take part in what he would call 'the decision-making process'. ${ }^{19}$

${ }^{18}$ Alexis de Tocqueville, Democracy in America and Two Essays on America (Gerald E. Bevan trans., Isaac Kramnick ed., London: Penguin, 2003 [1835]) 315 (I.2.8). Before Tocqueville Edmund Burke has expressed similar ideas. For this and a more general account of pre-Revolutionary American legalism see Thomas C. Grey, "Origins of the Unwritten Constitution: Fundamental Law in American Revolutionary Thought," 30 Stanford Law Review 843, 889-90 (1978).

${ }^{19}$ Hart, supra note 5 , at 89. 
Simply put, politics is a more participatory affair in the U.S. than in Britain, and going to court is simply one way of participating in politics in the United States. To be sure, there have been many critics, both popular and academic, of the excessive legalism in American life, complaining about too many laws, too many lawyers, and too much faith in the redeeming powers of law. But these persistent complaints need to be repeatedly made exactly because of the staying centrality of law in American political life. They need to mentioned against the background of statement such as "[1]itigation is an important political activity: courts exercise political authority, modify substantive laws, and allocate resources. ... Litigation declares and changes fundamental cultural values." ${ }^{20}$ (It is hard to imagine such a statement being made in the British context.)

The result of all this is a very different understanding of the relationship between law and politics in American law from the way this relationship is understood in Britain. This makes the fears of law becoming indistinguishable from politics more pressing; at the same time it implies that many of the institutional solutions for maintaining the rule of law that were adopted in British law are simply not available in the United States. The responses adopted in the American context therefore tended to be utterly different. Once again I can only mention briefly a few of them.

(1) Giving up: perhaps the most radical response to the difficulty is to give up on the attempt to maintain the separation between law and politics. The nomination proceedings of Supreme Court justices are now televised and openly political. In many states judges are elected and can be removed from office by the public. There is a thriving industry of scholarship produced by political scientists assessing court decisions in terms of their political orientation, and in response to the challenge that the law is political some scholars have even openly celebrated "political courts." ${ }^{\text {"1 }}$ The situation in Britain could hardly be more different. As one of the few political scientists to take an interest in the workings of the courts put it, "[i]t is possible for students of British government to pursue their studies in blissful ignorance of the contents of even the existence of the law reports." ${ }^{22}$ Compared with literally hundreds of books and articles by political scientists

${ }^{20}$ Richard L. Abel, “The Real Tort Crisis-Too Few Claims,” 48 Ohio State Law Journal 443, 454-55 (1987). Or consider the following words: "American common law is both more democratic and more dynamic than its British counterpart. The people play a larger role in American than in British common law, and the common law plays a larger role in the American than in the British system of governance." Carl T. Bogus, Why Lawsuits Are Good for America: Disciplined Democracy, Big Business and the Common Law (New York: New York University Press, 2001) 41.

${ }^{21}$ See e.g., Terri Jennings Peretti, In Defense of a Political Court (Princeton: Princeton University Press, 1999).

22 Gavin Drewry, "The GCHQ Case-A Failure of Government Communications," 38 Parliamentary Affairs 371, 373 (1985). The picture today is largely the same. See Gavin Drewry, "A 
examining the relationship between law and politics in the American context from every possible angle, there is an astounding dearth of studies of this sort in Britain.

(2) Theories of interpretation: the obsession with theories of interpretation at both the statutory and constitutional level are a mark of the desire to maintain a way of being able to extract the content of law in a way that need not deny the political content of the law. Certain approaches such as originalism and textualism present themselves as antidotes to the dangers of politicization of the law. Other approaches, like Dworkin's (whose approach I discuss below), address this difficulty by acknowledging the political character of the law, but by trying to show how this can be reconciled with the rule of law. Once again, it is notable that such debates simply do not exist in the UK.

(3) Economic analysis of law (and "theoretical" scholarship more generally): economic analysis of law has proven a remarkable success in the United States, but it has not had much impact in Britain. It is tempting to explain this disparity with the American obsession with theory and contrast it with English anti-intellectualism, but there is, I think, a deeper reason for this difference. In the British context economic analysis is perceived as an alien influence that could potentially lead to undermining the integrity of the law (its 'self-understanding'). It is thus not merely pointless, it is potentially dangerous. I suspect that the success of economic analysis of law has much to do with the need to maintain objectivity in the face of law deeply infused with politics. Since doctrinal analysis is no longer perceived as a sufficient barrier from the impact of politics-this is the realist legacy that has never had much impact in Britain-at least part of the initial enthusiasm with economic analysis has to do with the fact that it seemed to its proponents to provide precision and objectivity, something that traditional methods of legal reasoning not able to provide.

I could list many other ways in which the fundamental difference in understanding the relationship between law and politics manifest themselves in these two legal systems. Political activism in the United States is quite often legal activism. There is much less of that in Britain. (Of course, this may only reflect political activists' prediction that such a course of action would be a waste of time and money; but that is exactly the point.) Additional examples include the differences in the methods for nominating judges in the two countries and the place of law in public discourse (U.S. Supreme Court decisions are commonly front page news, but those of its British counterpart much more rarely). If I were to summarize the difference between the two positions in a sentence I would put it this way: the study of the American Constitution is, by and large, a study of American

Political Scientist's Perspective" in The Judicial House of Lords 1876-2009 (Oxford: Oxford University Press, Louis Blom-Cooper et al. eds., 2009) 439. 
constitutional law; the study of the British constitution is, to a much greater degree, the study of British politics.

No doubt the sketch I offered above is very schematic, and on each side there is now growing appreciation of the virtues of the opposing view. In Britain even before the adoption of the Human Rights Act there were those who sought to find a basis for judicial review of legislation in the principles of the common law. In the United States, by contrast, after years in which judicial review was perceived as the greatest gift American politics has bestowed on the world, there are now those who think the U.S. will be better off without it. But in both cases these are still minority views and they are battling very entrenched ideas. It is also possible that British law may be subjected to a kind of "critical legal studies" attack that would show that all the mechanisms mentioned above to keep law outside politics fail to do so, and British law is no less political than American law. And yet at least at the level that legal philosophers seem to be interested in, that of officials' attitudes from the internal point of view, the "self-understanding" of British law(yers) is fundamentally different from that of American law(yers).

\section{Back to the Jurisprudential Fray}

I suspect the response of many legal philosophers to what I have said so far will be that it is all very interesting, perhaps even true, but that this is not jurisprudence, and has little to do with its concerns. For the general view among them is that "in spite of many variations in different cultures and in different times, [law] has taken the same general form and structure." ${ }^{23}$ Most legal philosophers accept, or more precisely assume, the correctness of this statement and have therefore left the sort of matters I discussed in the last section to others. Or so it would at first sight seem. In this section I consider the place in which this debate has taken place in jurisprudence. I begin by examining the respective views of Hart and Dworkin and show that they reflect very different views on this matter, and ones that are in accordance with the dominant view on the relationship between law and politics in Britain and the United States, respectively. I then turn to another location in which the debate may be glimpsed, the debate between inclusive and exclusive legal positivists, and I argue that rather than address the issue, this debate highlights the limitations of the approach, strongly connected with the nature of law project, that gives central place to the question of legal validity.

\footnotetext{
${ }^{23}$ Hart, supra note 12 , at 240.
} 


\section{The Different Ways of Understanding the Connection between Law and Politics}

I started by distinguishing between Hart and Dworkin's perceptions of the other's native country, and I suggested that their respective theories of law may have been influenced by their perception in the local ways of the law in their own native country. This suggestion is not usually well respected among legal philosophers; Michael Moore considered it the sort of mistake one occasionally hears from students who are just embarking on their jurisprudential studies. ${ }^{24}$ Nonetheless, I will try to demonstrate that there may be deep and important truth in this view.

Consistent with my characterization of the relationship between law and politics in Britain, there is in fact very little about the matter in Hart's work, and whatever is found is almost always found in the context of discussing American law. ${ }^{25}$ Despite the fact that he clearly recognized, as the quotes above indicate, the differences between American and British political cultures and has also recognized the very different role that law plays in American law than in British law, he apparently did not think this poses a challenge to his views on the general nature of law. This, of course, is consistent with his view that there are underlying similarities between legal systems. It is, however, equally consistent with the possibility that Hart generalized from his own image of the British legal system to a general view about what law is.

Matters are quite different in the case of Dworkin. For him the constant contact between law and politics is perhaps the central background problem that calls for solution. Dworkin therefore starts his analysis at a point that those who wish to maintain the separation of law from politics would already find unacceptable: "Judicial decisions," he says, "are political decisions." 26 Thus, the separation between law and politics, in the way it is understood in British law-two (largely) non-overlapping domains-is off the table from the start. Instead, Dworkin seeks to solve the problem by relying on a distinction between what I will designate as "politics" and "Politics." The former is what one sees on TV: spin, corruption, simplistic slogans, talking points instead of argument. The other, Politics, is commitment to principle through the exploration of the moral requirements involved in living in a community. The distinction between "politics" and "Politics" is mine, not Dworkin's, but he effectively adopts it when he says that in a community governed by "the model of principle" members of the community "accept

\footnotetext{
${ }^{24}$ Michael S. Moore, Educating Oneself in Public: Critical Essays in Jurisprudence (Oxford: Oxford University Press, 2000) 80-81.

${ }^{25}$ See H.L.A. Hart, "American Jurisprudence through English Eyes: The Nightmare and the Noble Dream," in Essays in Jurisprudence and Philosophy (Oxford: Clarendon Press, 1983) 123, 124-25.

${ }^{26}$ Ronald Dworkin, Taking Rights Seriously (Cambirdge: Harvard University Press, rev. ed., 1978) 88; Dworkin, supra note 4, at 146.
} 
that they are governed by common principles, not just by rules hammered out in political compromise." And he adds: "Politics has a different character for such people. It is a theater of debate about which principles the community should adopt as a system...."27

What is the role of law in this? Dworkin's answer is that law, properly understood and practiced, is true Politics. The first step in the argument is that "our government shall be republican rather than despotic," 28 the second is that law is the main means for promoting this republican ideal:

We have an institution that calls some issues from the battleground of power politics to the forum of principle. It holds out the promise that the deepest, most fundamental conflicts between individuals and society will once, someplace, finally, become questions of justice. I do not call that religion or prophecy. I call it law..$^{29}$

Law and lawyers thus have a dual role within the American polity: one is to elevate by their example politics into Politics; the other is to limit the domain of politics by transferring certain questions from politics to law (and thus to Politics) if politics cannot be transformed into Politics. The first strategy is in view in Law's Empire when Dworkin argues that political decision-making should be based on the same principles and reasoning that guide legal decision-making. ${ }^{30}$ Elsewhere Dworkin explains that political institutions could rise to the level of Politics only under what he calls "partnership democracy," which, as its name indicates, is distinctive for its participatory view of democracy-one that works to encourage the kind of political debate he finds in the workings of the courts.

However, when the political community fails to create this form of democracy Dworkin is clear in favoring the second strategy: "individual citizens can ... exercise the moral responsibilities of citizenship better when final decisions involving constitutional

${ }^{27}$ See Ronald Dworkin, Law's Empire (Cambridge: Harvard University Press, 1986) 211; see also Ronald Dworkin, Freedom's Law: The Moral Reading of the American Constitution (Cambridge: Harvard University Press, 1996) 344, where Dworkin contrasts constitutional adjudication with "ordinary politics." For comparison consider Bernard Crick, In Defence of Politics (London: Continuum, 5th ed., 2000), a book that has a good claim to represent the classic vision of British politics. In it Crick writes: “Politics' ... simply summarizes an activity whose history is a mixture of accident and deliberate achievement .... It is not as such motivated by principle .... Political principles are, whatever they are, principles held within politics“. Ibid. at 32 (emphasis added). See also ibid. at 47.

${ }^{28}$ Dworkin, Freedom's Law, supra note 27, at 111.

${ }^{29}$ Dworkin, supra note 4, at 71 . Dworkin offers a (highly romantic and not very plausible) explanation of how law achieves this appears in Dworkin, Freedom's Law, supra note 27, at 31, 345.

${ }^{30}$ See Dworkin, Law's Empire, supra note 27 at 184 -86. It is also arguably the underlying idea in his book Is Democracy Possible Here?: Principles for a New Political Debate (Princeton: Princeton University Press, 2006). I criticize his argument that book in Danny Priel, "In Search of Argument," 86 Texas Law Review 141 (2007). 
values are removed from ordinary politics and assigned to courts, whose decisions are meant to turn on principle, not on the weight of numbers or the balance of political influence." 31

But even in a partnership democracy, even in court, how can we know that such debates would give us the objectively right answer to the questions of Politics? The answer, quite simply, is that the right answer is the best answer to come out of the debate. This crucial point about Dworkin's position is central to his thinking: the right answer is not "out there," it is simply what emerges as the "winner" in a principled debate. It is always open to challenge, but the objectively right answer means, for him, nothing more than the best answer in Political discourse.

Although Dworkin's particular views depend on various arguments that many do not share, it is important to stress that the general outline of this view belongs to a fairly familiar concern with articulating a response to perhaps the fundamental dilemma of American constitutional law, that of reconciling republican self-government in which law comes from "We the people" of the Constitution's preamble with the higher law, the "unalienable Rights," of the Declaration of Independence. To see this we must step outside the narrow bounds of analytic jurisprudence. There are many examples of discussions that deal with this matter in the constitutional and jurisprudential thought in the United States, ${ }^{32}$ but here I can only mention one. In a well-known essay by Owen Fiss, "Law and Objectivity" Fiss sought to address the challenge to objectivity posed by certain then-emerging critical scholars. ${ }^{33}$ Proponents of this "new nihilism" contended, as Fiss put it, that "[a]ll law is masked power." ${ }^{34}$ Fiss's response was somewhat different from Dworkin's: unlike the latter who denied the intelligibility of external criticism Fiss acknowledged it and even relied on it to distinguish between internal legal criticism and

\footnotetext{
${ }^{31}$ Dworkin, Freedom's Law, supra note 27, at 344; Dworkin, supra note 26, at 85.

${ }^{32}$ See Christopher G. Tiedeman, The Unwritten Constitution of the United States: A Philosophical Inquiry into the Fundamentals of American Constitutional Law (New York: G.P. Putnam's Sons, 189o); Edward S. Corwin, "The Basic Doctrine of American Constitutional Law," 12 Michigan Law Review 247 (1914); Edward S. Corwin, "The 'Higher Law' Background in American Constitutional Law" (pts. 1\&2), 42 Harvard Law Review 149, 365 (1929); Charles Grove Haines, The Revival of Natural Law Concepts: A Study of the Establishment and of the Interpretation of Limits on Legislatures with Special Reference to the Development of Certain Phases of American Constitutional Law (Cambridge: Harvard University Press, 1930); Thomas C. Grey, "Do We Have an Unwritten Constitution," 27 Stanford Law Review 703, 70809, 715-17 (1975); Grey, supra note 18; Suzanna Sherry, “The Founders' Unwritten Constitution,” 54 University of Chicago Law Review 1127 (1987).

${ }^{33}$ Owen Fiss, "Law and Objectivity," 34 Stanford Law Review 739 (1981). This essay was reprinted (under the title "Objectivity and Interpretation") together with other essays exploring similar ideas in Owen Fiss, The Law as It Could Be (New York: New York University Press, 2001) 149.

${ }^{34}$ Ibid. at 151.
} 
external ethical (or religious) criticism. But what looks at first like a significant difference turns out to be quite minimal, for as Fiss put it, "[e]ndogenous change is always preferred ... [and therefore $\mathrm{t}$ ] he external critic struggles to work within the law....."35

One need not accept Fiss's romanticized view of American law to recognize in his words a particular vision of addressing the challenge to the objectivity of law, that seeks to find it through engagement in moral and political debate within an "interpretive community." ${ }^{36}$ The judges' authority derives from the fact that they "are insulated from the political process" (i.e., what I called politics), but that is so in order for them "to engage in a special kind of dialogue over the meaning of [public] values" (i.e., what I called Politics). This judicial engagement with public values is "an essential part of the process through which a morality evolves and retains its public character." ${ }^{37}$ For this reason "courts should not be viewed in isolation but as a coordinate source of governmental power, and as an integral part of the larger political system." 38

I hope it is clear from this discussion where exactly Dworkin's right answer thesis fits within this picture. In the view of law as Politics, its fundamental point is not guidance but participation, for the right answer is what emerges from engagement in the debate; however, the judge's role in this debate is not that of a follower (of rules set elsewhere), but primarily as that of a moral leader. For this reason we even find in Dworkin, an exhortation for (as Hart put it) the "the sage ... [who] may be in the university" to provide the answer. ${ }^{39}$ Dworkin's answer, then, is not simply that morality contains right answers to moral questions, and since it is part of the law, law contains right answers too. At bottom his view holds that law can transform political debate and in this way avoid the problem of objectivity. If one accepts this view the audacious right answer thesis becomes trivial, you might even say tautological. But in the Hartian perspective it is almost incomprehensible, for this view is premised on the idea that when politics is introduced into the law, political disagreement is simply reproduced within the law. It is hard to see

${ }^{35} \mathrm{Ibid}$. at 159 ; see also ibid. $160-62$ for an elaboration on the ways in which appeal to morality is required to maintain the objectivity of law.

${ }^{36}$ Ibid. at 170.

${ }^{37}$ Ibid. at 199.

${ }^{38} \mathrm{Ibid}$. at 54, see also ibid. at 34-35. For another similar suggestion see Sotirios A. Barber \& James E. Fleming, Constitutional Interpretation: The Basic Questions (New York: Oxford University Press, 2007) 156 (the right approach to constitutional interpretation "can only mean an interpretation of the Constitution that tries to redeem its expressed claim to be an instrument of justice, the general welfare, and the other goods listed in the Preamble."). There are many others.

${ }^{39}$ Recall: "The courts are the capitals of law's empire, and judges are its princes, but not its seers and prophets. It falls to philosophers, if they are willing, to work out law's ambitions for itself, the purer form of law within and beyond the law we have." Dworkin, Law's Empire, supra note 27, at 407. 
how that could aid the search for legally correct right answers or guarantee the objectivity of law. This view is evident when Hart criticizes those who think that "there is no central element of actual law to be seen in the core of central meaning which rules have, that there is nothing in the nature of a legal rule inconsistent with all questions being open to reconsideration in the light of social policy." ${ }^{30}$ For Hart to recognize the existence of law is to recognize a domain in which politics, even Politics ("social policy"), cannot touch.

\section{Legal Validity?}

One occasionally gets a glimpse of these issues in contemporary jurisprudence, but it is mostly just of flickering phantasms rather than the real thing. In particular, the issue is in the background of the debate between "inclusive" and "exclusive" legal positivists as it touches on the question of limits on lawmaking power. ${ }^{41}$ In this context the difference between the British and the American constitutions is explained by saying that there is no difficulty with constrained sovereignty, something that the Americans have chosen to have whereas the British rejected. I believe it is not hard to feel that this question and the competing answers given to it (roughly, the law directs us outside, or the law incorporates morality) does not quite grasp the issue at hand.

This is but one of the difficulties with the misguided approach (to which Hart and Kelsen are most responsible) of treating legal validity as the fundamental concept of jurisprudence. I have argued against this view elsewhere, and will not repeat my arguments here, ${ }^{42}$ but instead I will try to illustrate the shortcomings of the perspective that tries to explain the difference between American and British law discussed above as emanating from their having different tests of legal validity. This view fails to capture the sense in which the British constitution is fundamentally a political, not a legal, entity (it is difficult to talk about a "document" in this context). It is a constitutional structure in which "[e]verything that happens is constitutional. And if nothing happened that would be constitutional also." ${ }^{\prime 3}$ It is from this that law is understood as simply the voice (the

${ }^{40}$ H.L.A. Hart, "Positivism and the Separation of Law and Morals," 71 Harvard Law Review 593, 615 (1958) (emphasis in original), reprinted in Essays in Jurisprudence and Philosophy, supra note 25, at 49, 72. Again the view Hart rejects is a neat summary of Dworkin's view.

${ }^{41}$ See already in Hart, supra note 12, at 72, 106, 247.

${ }^{42}$ I have argued against this view in Dan Priel, “The Place of Legitimacy in Legal Theory," available at http://ssrn.com/ abstract=1566825. See the appendix for a graphic summary of my argument there.

${ }^{43}$ J.A.G. Griffith, “The Political Constitution," 42 Modern Law Review 1, 19 (1979). Griffith's terms are stark, but the idea is an old one. See Walter Bagehot, The English Constitution (Richard Crossman ed., 1963 [2nd ed., 1872]) 221 ("The ultimate authority in the English Constitution is a newly-elected House of Commons"); Grey, supra note 18, at 866. On the decline of the idea of fundamental law in 
"command," if you don't mind my Austinism) of whoever happens to be in power. Sovereignty on this view is the power to make laws. This is a power that the, otherwise unlimited, sovereign can choose to limit is an act of self-binding. This is, effectively, the way Hart interprets the United States Constitution, and this is how today the Human Rights Act is reconciled with the doctrine of Parliamentary sovereignty. By contrast, in the United States the Constitution created by the people is thought to award political power, otherwise non-existent. As such the law is understood fundamentally not as the manifestation of power, but as what sets the limits on it. In the British picture judicial engagement in politics is ultimately an illegitimate attempt to usurp political power, in the latter it is a necessary, inevitable outcome of the need to set the limits of legitimate power.

These two views emanate from two very different underlying political theories about what makes the use of power legitimate, and yet all this is treated as irrelevant to understanding the nature of law, and one might add exactly because they are political in nature. But as we now see, the differences between the two countries' underlying political theory result in ways of understanding and structuring law that in very fundamental ways are almost opposite of each other. And once we see this, much of what I said above, that within the "validity-first" picture remains inexplicable, begins to make sense. The different place of politics with relation to law, and the different responses to the problem of objectivity we have seen above, are the result of different understandings of what law is, and these can be traced back to the U.S. and Britain different political traditions.

\section{The Implications for the Search for the Nature of Law}

It is an interesting question, although one that I could not possibly address in much detail here, why legal philosophers have spent so much attention on obscure questions relating to the connections between law and morality, but have said virtually nothing about the connections between law and politics. But if the law-morality interface is considered crucial for understanding the nature of law, so, one would think, is also the case with the law-politics interface. At least part of the answer probably has to do with the fact that by the standards of contemporary legal philosophy much of what I said so far would probably be dismissed as not sufficiently philosophy. There were just too many facts, too much history, even a citation to a case.

Britain see J.W. Gough, Fundamental Law in English Constitutional History (Oxford: Clarendon Press, new ed., 1961) 168-207. 
In proper philosophical style, then, let me present a syllogism:

(1) There is no right answer to what constitutes "true" politics; there is, if you wish, no non-political "nature" to politics to be discovered through conceptual analysis.

(2) Different states have different forms ("conceptions") of politics that reflect their different values and history.

(3) There are connections between law and politics.

(4) Different understandings of politics result in different roles, understandings, forms ("conceptions") of law in different states.

(5) The different conceptions of law go to the heart of what on any plausible view of the matter counts as the nature of law.

Hence: (6) The search for the (single, unique) nature of law is misguided.

I did not argue for (1), but I assume (and hope) it would not be controversial. Denying it is hardly going to help the search for the nature of law, for that would only mean that for the sake of an account of the latter, legal philosophers (unless they deny (3)) would have to develop a side-specialty of identifying the true nature of politics. In any case, my demonstration of (2) above can be seen as validation of (1) as well. (3) too is, I think, uncontroversial. It is the remaining premises, (4) and especially (5), that are likely to evoke most resistance, but my argument in the last section has shown, I hope, the very different understanding of politics in the two countries, and how result in a profoundly different understanding of what law is.

Those who wish to reject my argument might contend that at best what my argument shows is the need for making discussions on the nature of law more abstract. John Gardner once described Dworkin's work as that of a "theoretically ambitious lawyer," 44 suggesting that this is not legal philosophy. Perhaps my argument would be classified in the same way: exactly because my discussion reveals such differences between American and British law it is irrelevant to the question of the nature of law. Assuming the search for the nature of law seeks to identify those things that different legal systems have (necessarily) in common, and assuming the relationship between law and politics is not one of them, then this shows the matter is not part of legal philosophers' purview. Rather than a reason for criticizing legal philosophers, you might say my discussion so far shows that they have been doing a good job by avoiding these issues.

One may define the term "nature of law" any way one wishes and it is definitely possible to define it to mean those necessary features we happen to find in all legal systems. Even then I think my argument above shows that one is likely to find much, much less than most legal philosophers seem to think. More importantly, if the nature of law simply means those things that are necessarily true of all legal systems, then one

\footnotetext{
${ }^{44}$ John Gardner, “The Legality of Law,” 17 Ratio Juris 168, 173 (2004).
} 
would then wonder why this question is of any interest. (Is philosophy in the business of collecting necessary truths about things in the world?) The search for the nature of law was presumably considered valuable, because it was believed it that through it one could learn something valuable about an existing social practice that in all sorts of ways we encounter every day of our lives. It is not at all clear that whatever emerges from the search for the "nature of law" so defined would be in any way illuminating about the practice of law. This solution to my challenge, then, seems more like admission of defeat.

If the search for the nature of law is to be meaningful, and if it is to bear some resemblance for what most people mean when they talk about the "nature of X" such inquiry should be understood in quite different terms. I propose, informally, that a fact belongs to the nature of a thing if it explains many other facts about it. Slightly more formally, a fact $F$ is part of the nature of social practice $S$ if (and only if?) it figures in an explanation of many features of $S$. Even the more formal definition is still imprecise, but for my purposes here it will do. I propose that the way the relationship between American and British law and politics is part of each legal system's nature, as defined here, for one thing we have seen above is that the relationship between each legal system and politics was part of the explanation of very many aspects of each; and though I have said nothing about it, they are also relevant for explaining some of the differences between the content of the laws of those legal systems.

All this does not amount to a logical proof, but it does amount to a demonstration that two legal systems have a very different understanding of what law is as a result of their different understanding of the relationship between law and politics, and that this difference cannot be captured in terms of legal validity, currently the central organizing concept of analytic jurisprudence. There is, however, a logical challenge I can direct at defenders of the nature of law project: the issues raised in this essay can be deemed irrelevant only if American law and British law belong to the same kind, otherwise the differences between them are simply irrelevant to the question of each legal system's respective nature. In other words, there is a different way of understanding my argument, i.e. as the claim that American law and British law are different kinds, in which case the set of facts I described about each law may be necessary for understanding its nature but irrelevant to understanding the nature of the other. Proponents of the nature of law assume without argument that American and British law are two species of the same kind, but from a logical point of view there is no telling whether they are right on this matter or whether my alternative suggestion is correct. Since there is no fact of the matter on this question, the assumption that they are-an assumption that is crucial for the entire enterprise of the search for the nature of law-is unwarranted. Furthermore, this assumption can only make sense if one implicitly assumes some further substantive views about what law is. The whole enterprise is thus in some sense circular as it can only get off 
the ground by presupposing the truth of certain premises that are presented at the end of the inquiry as findings about the nature of law. (This problem is complicated many times over when other legal systems, contemporary, historical, some may even want to add hypothetical, are added to the story.)

To amplify this last point imagine you had been asked to offer an account of the nature of American law or the nature of British law, a sort of account of the central features of the legal system, one that includes the understanding of lawyers in each of these legal systems as to the enterprise they are engaged in. We could then conclude that British and American law belong to the same kind only at the end of our inquiry, if we found out that the accounts we offered turned out to have a roughly identical core (the nature of law) and some differences at the edges (which account for the unique features of each legal system). But if we tried that and found out that the accounts were conflicting, that would imply that these two legal systems do not belong to the same kind. A different way of putting this point is that one can embark on the search for the nature of law only after having an account of at least some different legal systems. This essay can be read as an attempt to show that if we tried doing that, we would find that the natures of at least the British and the American legal systems conflicted. Of course, I may be wrong about this, but until something like this is tried-and I know of no legal philosopher writing on the nature of law who tried to do that-the entire project rests on wholly questionbegging assumptions.

Perhaps, however, we may understand the search for the "nature of law" more weakly, i.e., as not actually concerned with finding the nature of law. Instead this term might simply designate an attempt to look at law from some greater distance, without any classificatory commitment. Is the difference between my views and those of legal philosophers looking for the nature of law nothing more than that they prefer the long shot view whereas I am more interested in the close up? I do not deny that standing at some "distance" from a phenomenon can reveal what a closer look may miss. ${ }^{45}$ Even understood in this more relaxed way, however, there is a serious problem with it, for if this is the reason for the search for the nature of law, then the right distance from the object of inquiry is not to be determined by the object of inquiry. Rather, it has to be chosen by legal philosophers according to criteria that are external to the object of inquiry. Since there is no correct degree of "zoom" fixed by the object, the only appropriate level way of choosing between various possible distances must be determined according to instrumental standards pertaining to what we gain from the explanation. If that is the case, my view is that in their search for the nature of law legal philosophers

\footnotetext{
${ }^{45}$ See Frank Jackson \& Phillip Pettit, "In Defence of Explantory Ecumenism," in Mind, Morality, and Explanation: Selected Collaborations (Oxford: Clarendon Press, 2004) 163.
} 
have been standing too far from the law, and that some of the debates that preoccupied legal philosophers in the last few years under the banner of the nature of law were deeply unilluminating of their object of inquiry. Don't take my word for it: on this interpretation of the search for the nature of law, the lack of interest by others, legal academics, but also moral and political philosophers (let alone practitioners or lay people), is more than suggestive of the fact that the distance from the object chosen by legal philosopher is the wrong one.

Opting for the distant explanation can also lead to the opposite problem, viz. the tendency to assume the local and familiar is general and universal. I have already argued that this was the case in the work of both Hart and Dworkin. Let me illustrate this point with another example. A few years ago there was an internet debate on the question why Anglo-American legal scholars take relatively little interest in the work of Hans Kelsen and in deontic logic, both topics on which legal philosophers from continental Europe write much more. The debate attracted many prominent legal philosophers, who offered various explanations. ${ }^{46}$ I read this exchange and was struck by the fact that, with the exception of one fleeting comment (by an Italian, made with regard to Kelsen), no-one mentioned what I thought was the obvious explanation. Kelsen's legal thought, despite his many years in the United States, remained firmly rooted in a particular conception of law that is closer to what one finds in civil law systems. Once it is recognized that for all its abstraction Kelsen's approach fits some legal systems better than others, the puzzle is solved. The same is true of deontic logic. Deontic logic would be considered important for analyzing legal argument within a legal system that puts a premium on deductive argumentation. This is exactly what one finds. A prominent German legal scholar has recently written that even today "[t]he typical German judgment, like its French counterpart, strives after the ideal of deductive reasoning." ${ }^{47}$ By contrast, legal philosophers from common law jurisdictions, who from Day 1 of law school hear that "[t]he life of the law has not been logic; it has been experience," ${ }^{38}$ are much less likely to think that deontic logic is going to capture anything important about the law.

46 See http://prawfsblawg.blogs.com/prawfsblawg/2007/10/why-no-deontic-.html; http://prawfs blawg.blogs.com/prawfsblawg/2007/10/why-no-kelsen.html; http://leiterlegalphilosophy.typepad.com/ leiter/2007/10/why-dont-amer-1.html (all visited, Apr. 8, 2011).

${ }^{47}$ See Reinhard Zimmermann, "Characteristic Aspects of German Legal Culture," in Introduction to German Law (The Hague: Kluwer Law International, 2005) 1, 27, also at 38; see also B.S. Markesinis, "Conceptualism, Pragmatism and Courage: A Common Lawyer Looks at Some Judgments of the German Federal Court,” 34 American Journal of Comparative Law 349, 366 (1986).

${ }^{48}$ O.W. Holmes, The Common Law (Boston: Little, Brown, 1881) 1. American philosophers have expressed similar views. See John Dewey, "Logical Method and Law," 33 Philosophical Review 560 (1924); Morris R. Cohen, "The Place of Logic in the Law," 29 Harvard Law Review 622 (1916). For 
I point out these vestigial localisms in supposedly general theories of the nature of law not in order to castigate particular legal theories for their insufficient generality, but to point out that legal philosophers' tendency to stand far away from legal practice, their relative lack of interest in the nitty-gritty details of the organization of particular legal systems, adopted in the name of the search for the nature of law may result in too quick generalizations from few familiar cases.

Perhaps noticing the difficulties with talking about the nature of law in general, several legal philosophers have turned in recent years to talking about "our" concept of law. ${ }^{49}$ This seems like a more modest claim than the universalistic search for "the" nature or concept of law, but the problem of demarcation mentioned above arises here as well: Quite simply, there is no logical way of demarcating "our" concept of law without circularity unless we have a non-question begging way of demarcating who "we" are, and none of those who suggested this idea have even hinted towards a way of addressing this question. This is not a fanciful complaint. In challenging the search for the nature of law I relied not on anthropological studies of small pre-industrial communities living in the thick of the Amazon rainforests, not on the law of an ancient and now extinct political community, not on the law in contemporary Eastern Europe, ${ }^{50}$ not even on the distinction between common law and civil law that some have suggested involved some fundamentally different ways of thinking. ${ }^{51}$ I looked at the two legal systems from which the most prominent analytic legal philosophers hail, two legal systems that share a long history. If "our" does not include both of them, I do not see what this word is supposed to cover.

At this point the challenger may reply that I am wrong to say that we have no way of knowing that American and British law are not the same kind: after all, people treat them as belonging the same kind, which is why, for example, they consider it a valuable exercise to compare them. This response, however, is both unconvincing and self-defeating. It is

many other statements expressing the same idea from English and American judges and scholars see Stephen Waddams, Dimensions of Private Law: Categories and Concepts in Anglo-American Legal Reasoning (Cambridge: Cambridge University Press, 2003) 1-2.

${ }^{49}$ See in particular Joseph Raz, Between Authority and Interpretation (Oxford: Oxford University Press, 2009) 94-95.

${ }^{50}$ Neal Ascherson, "Law v. Order," London Review of Books, 20 May 2004, at 22 ("when [Putin] says 'law' he means what we would call 'order"). For more on what law means in contemporary Russia see Jeffrey Kahn, "The Search for Rule of Law in Russia," 37 Georgetown Journal of International Law 353 (2006); Marina Kurkchiyan, "The Illegitimacy of Lwa in Post-Soviet Societies," in Law and Informal Practices: The Post-Communist Experience (Oxford: Oxford University Press, D.J. Galligan \& Marina Kurkchiyan eds., 2003) 25.

${ }^{51}$ See Pierre Legrand, “Against a European Civil Code,” 6o Modern Law Review 44 (1997). 
unconvincing, because it is asserted rather than shown. The fact that people use the same word to describe both is not sufficient to tell us that the word is used to refer to the same kind. (We are, after all, repeatedly reminded that legal philosophy is not lexigraphy.) This usage is perfectly acceptable for everyday purposes, but it does not require commitment to the view that the things described by the same word share certain necessary features. In fact, my guess is that if you asked some British lawyers what they thought of American law, many of them would reply "it is not really law, it is politics masquerading as law," 52 or at least would have said that law in U.S. is a very different beast from law in British.

This answer is also self-defeating because if we take people's attitudes seriously then we should pay at least as much attention to their profound thoughts and selfunderstanding of their own legal system than to their superficial comparisons with others. Put differently, one cannot invoke people's attitudes at one point and ignore them completely at another. And it has been exactly my claim that those attitudes are profoundly different in Britain and the United States.

\section{Some Further Objections}

I foresee four additional objections to the position taken here. The first is that the argument must be wrong because the existence of debate and controversy on the question of the nature of law shows that there is something that the disputants are talking about. Andrei Marmor says at one point that "controversy over the content of a rule of recognition does not prove that there is no such a rule. Even when there are several ways of understanding a rule (or anything else for that matter), there must be something there that people can understand differently and argue about." ${ }^{33}$ The context of the argument is specific, but Marmor's parenthetical remark shows he considers his point to be general. Transferred to our context the argument would be that the fact that people disagree about the nature of law shows that such a thing exists. Unfortunately, this is a bad argument. Controversy may be the result of shared mistaken belief over the existence of something that in fact does not exist. No-one (I hope) would infer the existence of God from the existence of debates about the nature of God. In our context, debates about the nature of

\footnotetext{
${ }^{52}$ I have not conducted a survey but for two contemporary academic lawyers who come close to saying just that see Robert Stevens, "Torts" in The Judicial House of Lords 1876-2009, supra note 22, at 629, 651; Peter Birks, "Equity in Modern Law: An Exercise in Taxonomy," 26 University of Western Australia Law Review 1, 98-99 (1996).

${ }^{53}$ Andrei Marmor, Positive Law and Objective Values (Oxford: Oxford University Press, 2001) 6. Oddly, he directs this argument at Dworkin, who probably "invented" it.
} 
law could exist so long as participants share the mistaken belief that such a thing exists. The purpose of this essay is exactly to challenge this belief. ${ }^{54}$

A second objection is the opposite of one of the objections considered above, i.e. that I have rigged the argument in my favor by my choice of two very different legal systems. There is American exceptionalism (including American legal exceptionalism) on one side and British exceptionalism (not having a written constitution) on the other. If I had chosen different countries, I would not have gotten such different outcomes. There are, however, several problems with this objection. One is, of course, that in some respects the American and the British legal systems are fairly close: they are both legal systems of Western developed countries with a long shared history. And as already mentioned, these happen to be the countries from which the most prominent analytic legal philosophers come from, and it is very rare indeed to hear them thinking of either (or both) of these legal systems as somehow an outlier in the search for the nature of law (especially when the whole point of the search for the nature of law is to find those features from which there are no outliers). ${ }^{55}$ The most important point, however, is that once one starts looking closely virtually every country is "exceptional" in one way or another. French law and German law are the paradigmatic examples of civil law jurisdictions, and yet there are important fundamental differences between them; German law has served as the model of much Chinese law, but there are fundamental differences between them as well. This does not entail (nor did I argue) that each legal system has its own "nature," and nothing illuminating can be said about law in general. It says, however, that observations true of many, even all, legal systems should be the findings at the end of an investigation, not the starting point.

This point leads to the third challenge, and that is that my argument in fact shows that law has a nature, namely that the law is concerned with objectivity. The critic may even go on to quote me saying that there is "tension between the aims for objectivity in the law and its subject-matter." Can I make this statement without assuming law has some nature? This is an important point for clarifying the scope of my argument. First, I do not deny that there are certain observations true of both American and British law. There may even be observations true of legal systems more generally. But to observe at

${ }^{54}$ In fact, I argue elsewhere that the opposite is true: the existence of persistent controversy on jurisprudential question is a serious challenge to another aspect of the search for the nature of law, namely the claim that jurisprudence is descriptive. See Dan Priel, "The Simple Argument against Jurisprudential Descriptivism" (unpublished manuscript).

${ }^{55}$ For a rare (and perhaps for this reason, neglected) exception see P.S. Atiyah \& Robert S. Summers, Form and Substance in Anglo-American Law: A Comparative Study of Legal Reasoning, Legal Theory, and Legal Institutions (Oxford: Clarendon Press, 1987). See in particular the discussion on jurisprudence in ibid. at 256, 411-20. 
legal systems and notice some things they have in common is not philosophy, and it is best done with recognized fact-gathering techniques that, to put it gently, are not the mark of contemporary legal philosophy. Second, there may be some "philosophical" questions (whatever that means exactly) that arise with regard to many, perhaps even all legal systems. But these "puzzles," as I called them elsewhere, ${ }^{56}$ need not, singly or together, amount to anything that could plausibly be called the nature of law (unless one uses this term in the purely technical sense mentioned above), nor do these puzzles become less puzzling if they are found to be true of only some legal systems. Most importantly, there is no reason to think in advance that even if the same puzzle arises in all legal systems, that the answer to it will be the same in all legal systems. To pick a favorite puzzle, it is perfectly possible that we will have one explanation for the normativity of law in a contemporary modern welfare-state democracy and quite another one in a medieval feudal society. We have seen a different understanding of the relationship between law and politics in between British and American law; the differences may be even greater in a place where an absolute monarch declares "the state is me." Since law is not something that falls on societies from the sky with a note "take me or leave me" attached, it can be (and has been) molded according to the particular political culture in which it exists. This claim is uncontroversial with regard to legal content, but we have no basis to assume it stops there and does not affect other aspects of law.

The last objection I can foresee is that what I have argued so far is a kind of a skeptical claim. As such it may be an amusing intellectual game, but like other skeptical claims we should really ignore it and go on with our daily business, including philosophers' daily business, which has always been the identification of the nature of things. However, if my claim is "skeptical" in any sense, it is skeptical only with regard to a particular, and in historical terms recent, understanding of jurisprudence. In the English-speaking world it was, at the earliest John Austin who understood the domain of jurisprudence in this way (and I would argue that even he is a questionable case). Before him there is simply no-one that I know of, definitely not Bentham or Hobbes, who was concerned with the question of the nature of law in the manner this term is understood these days. It was only around fifty or so years ago that Anglophone legal philosophy turned in earnest to this question (in German-language jurisprudence things may have begun a bit earlier). This happened at a particular point in history, when other branches of Anglophone philosophy were also interested in questions of a similar kind; and yet in other areas these questions were fairly quickly abandoned: already in 1979 Brian Barry, who knew a thing or two about the time

\footnotetext{
${ }^{56}$ See the discussion of the difference between the nature of law and puzzles in Danny Priel, "Jurisprudence and Necessity," 20 Canadian Journal of Law and Jurisprudence 173, 193-95 (2007).
} 
and place in which this sort of inquiry flourished, wrote mockingly about questions of this sort, "I cannot remember when I last read a discussion about the criteria for a good cactus or an extra-fancy apple." ${ }^{\text {" }} 7$ It is, I think, no coincidence that the revival in political philosophy, pronounced dead in 1960s, began exactly at the time that these questions were abandoned, and by now, in many branches of philosophy the search for the "nature" of things is being challenged, or has been largely abandoned. ${ }^{58}$

\section{From the Nature of Law to Human Nature?}

Does this mean that it makes no sense to talk about the "nature" of law? If we mean by this term what it meant to most legal philosophers in the last fifty years, then the inevitable answer is "yes." 59 Perhaps, however, there is a completely different way of thinking about this question. Perhaps the nature of law is not a matter to be discovered by

${ }^{57}$ Brian Barry, “And Who Is My Neighbor?," 88 Yale Law Journal 629, 632 (1979). But unlike other areas of philosophy this sort of question seems to be alive and well in jurisprudence. See Julie Dickson, "Is Bad Law Still Law? Is Bad Law Really Law?", in Law as an Institutional Normative Order (Maksymilian Del Mar \& Zenon Bankowski eds., 2009) 161. It is notable that it is mostly legal positivists who seem concerned about these sorts of questions, whereas natural lawyers like Finnis and Dworkin dismiss them as unimportant. This should have alerted legal positivists to the fact that these natural lawyers are not in the business of giving an analysis of the nature of law, but rather of giving a political (non-neutral) account of law. Many of the apparent tensions Dickson finds in the work of Finnis, ibid. at 170-73, disappear once this point is realized. For a detailed explanation of the difference between the two projects, with special reference to the work of Dworkin, see Priel, supra note 42.

${ }^{58}$ See e.g., in metaphysics: Bas C. van Fraasen, The Empirical Stance (New Haven: Yale University Press, 2002) ch. 1 (entitled “Against Analytic Metaphysics”); in epistemology: Stephen P. Stich, The Fragmentation of Reason: Preface to a Pragmatic Theory of Cognitive Evaluation (Cambridge: MIT Press, 1990) 19-21 (section entitled "The Irrelevance of Analytic Epistemology") and Philip Kitcher, "The Naturalists Return," 101 Philosophical Review 53 (1992); in ethics: Stephen Darwall et al., "Toward a finde-siècle Ethics: Some Trends," 101 Philosophical Review 115, 123 (1992) (describing how "[m]oral philosophers shed the obsessions of analytic metaethics") and Mark Timmons, Morality Without Foundations: A Defense of Ethical Contextualism (New York: Oxford University Press, 1999) 15-30 (describing the move from analytic to post-analytic metaethics); in philosophy of mind: Jerry Fodor, "Water's Water Everywhere", London Review of Books, Oct. 21, 2004, at 17; and see generally Gilbert Harman, "Doubts about Conceptual Analysis," in Reasoning, Meaning, and Mind (New York: Oxford University Press, 1999) 138. They could all be wrong, of course, but to suggest that abandoning the search for the nature of law is somehow anti-philosophical displays lack of awareness on what some of the world's leading philosophers think is (and is not) philosophy.

${ }^{59}$ For the sake of completeness I should add that my argument here is not the only one I have advanced against this sort of inquiry. See Danny Priel, "The Boundaries of Law and the Purpose of Legal Philosophy," 27 Law and Philosophy 643 (2008); Priel, supra note 56. Against the "case study" approach of the present essay, the approach taken in these two essays in more abstract. 
a priori reflection on law, but rather by looking more at humans and their nature. This idea may sound new, but it is in fact one as ancient as jurisprudence, and it is only the lack of interest of most legal philosophers in the history of their subject (prior to 1961) that has obscured this point. It is part and parcel of the natural law tradition, and it is also central to the work of those often considered the first legal positivists, Thomas Hobbes and Jeremy Bentham. It is only the turn away from this idea in the work of Austin and especially Hart that jurisprudence lost touch with this idea, and consequently lost its way. ${ }^{60}$

The rejuvenation of this idea has been coming from different quarters. Building on work in psychology and anthropology that identified numerous traits and habits found in all human societies, ${ }^{61}$ there have been some attempts to extend these ideas to law. ${ }^{62}$ Without passing judgments on any of the particular ideas defended in these works, I will say that I am sympathetic to the view that scientific findings could contribute to questions that have traditionally been thought to belong to philosophy. ${ }^{63}$ It is worth bearing in mind, however, that at this stage the research this work is based on is still controversial, and the application of these recent findings to law raises further difficulties. I cannot discuss these issues here, but I wish to highlight two points about how different this approach would be from the currently dominant view in jurisprudence. First, these inquiries rely heavily on factual discoveries of social and cognitive scientists, whose methods are very different from those of contemporary legal philosophy. Second, the substantive results of this approach are also likely to look quite different from those of contemporary jurisprudence. The "direction" of their argument is from human nature to the nature of law, rather than from observations about law to the nature of law. Fully

${ }^{60}$ See Dan Priel, "Toward Classical Legal Positivism” (unpublished manuscript). Hart, I should add, flirted with such ideas in his brief discussion of the minimum content of natural law. See Hart, supra note 12, at 193-200. It contains some interesting, "Humean" remarks, but even these are mostly negative (i.e., an attempt to challenge what he considered to be mistaken views about human nature espoused by natural law theorists) and their relevance for understanding the content laws are likely to have, but not the basis for Hart's positive account of law.

${ }^{61}$ See Steven Pinker, The Blank Slate: The Modern Denial of Human Nature (London: Penguin, 2002) 435-39, passim.

${ }^{62}$ See, e.g., Robin Bradley Kar, "The Deep Structure of Law and Morality," 79 Texas Law Review 877 (2006); Michael D. Guttentag, "Is There a Law Instinct?," 87 Washington University Law Review 269 (2009); see also John Mikhail, "Moral Grammar and Intuitive Jurisprudence: A Formal Model of Unconscious Moral and Legal Knowledge" (2009) 50 Psychology of Learning and Motivation 27 (2009), which focuses more on the question of particular moral judgments, but reflects a similar spirit.

${ }^{63}$ See generally, Dan Priel, "Jurisprudence Between Science and the Humanities," 3 Washington University Jurisprudence Review (forthcoming 2011); Dan Priel, "Jurisprudence and Psychology," in New Waves in Philosophy of Law (Maksymilian Del Mar ed., forthcoming 2011) ch. 3. 
cognizant of the fact that there are considerable differences between legal systems, this sort of approach is unlikely to try to distil the few features that make something into a legal system, but rather try and identify what facts about human nature entail (if anything at all) about the shape legal institutions are likely to take. Though the aspiration is to identify some such universal tendencies, it does not require the discovery of necessary truths.

Ending on this note may seem to undermine the thrust of the whole essay. The essay seems to advance a kind of "relativistic" thesis, which aims to challenge the nature of law, but then suddenly in the end a "universalism" of sorts seems to be back. To me, however, this challenge only reflects one of the most difficult questions in the explanation of all of human affairs, namely how to reconcile universal human nature with immensely different cultures. Swings in popular and academic views on the matter-the sixties and seventies were the "relativistic," and now universalism is back in fashion ${ }^{64}$-reflect the extent to which this complex question may be influenced by shifting fashions, but it seems clear that there is quite a bit of both in all human societies, and that a complete account of social institutions would have to take account of both.

Legal philosophers may have thought that they could contribute to the universal end of the inquiry, but it increasingly looks as though philosophy can say relatively little on the question of human nature. Science has taken over this task, and philosophers can (at best) only look from the sidelines and suggest further avenues of inquiry. If philosophy is to make a contribution it must be elsewhere. It can be helpful in specifying the normative roles that different social institutions play in society, and perhaps even more than that, it can serve as the go-between trying to connect the general, scientific inquiry on human nature with the diverse, normative examination of diverse social institutions. That, however, would require legal philosophers to abandon their aloof attitude towards other methods of inquiry about law and try to integrate this learning into their work.

\section{Conclusion}

This is a story with an interesting twist. Much of the work in jurisprudence of the last fifty years has been concerned with the discovery of objective truth about the "nature" of law. What I argued is that to find the answer to this question one needs to understand the way the idea of objectivity in law is understood, and how different understandings of this idea,

${ }^{64}$ Consider these titles: Steven Pinker, The Language Instinct: How the Mind Creates Language (New York: HarperCollins, 1994); Steven Pinker, “The Moral Instinct," New York Times (Magazine), 13 Jan. 2008; Denis Dutton, The Art Instinct: Beauty, Pleasure, and Human Evolution (New York: Bloomsbury, paperback ed., 2010); Nicholas Wade, The Faith Instinct: How Religion Evolved Why It Endures (New York: Penguin Press, 2009); Guttentag, supra note 62. 
or more precisely how different legal systems responded to the problem of the objectivity of law because of the different ways in which the relationship between law and politics is understood in these legal systems. If one accepts that there is no one way of understanding the relationship between law and politics and that the way this relationship is understood touches upon and affects the most basic aspects of legal systems, then it follows that there is also no single answer to the question of the nature of law.

Why has this conclusion eluded some very sophisticated thinkers? One reason must be that the debate about the nature of law has been framed as a debate about the relationships between law and morality. Morality is usually thought to be immutable, ${ }^{65}$ which suggests that at least the relationship between law and morality would turn out to be some kind of universal conceptual truth. (This is true also of moral anti-realist legal philosophers such as Kelsen or Alf Ross.) But the focus on the relationships, necessary or otherwise, between law and morality has obscured from view a different, and arguably far more important, question about the relationship between law and politics. Understanding this relationship calls for more attention to law's daily workings-the way judges understand their position in relation to other branches of government, the way judges are appointed, the way they write their opinions, the way law is taught, and, as the quotes with which I began show, also the way political elites perceive the right way of solving social problems. One of the unfortunate implications of the focus on the "nature" of law within jurisprudence is that those working in jurisprudence have come to see all this as irrelevant detail, not sufficiently interesting or important for serious philosophical reflection. There has been, if you will, a growing gulf, almost a conceptual separation, between law and jurisprudence. If nothing else, I hope this essay has shown what detrimental effect this has had on legal philosophy.

\footnotetext{
${ }^{65}$ I say "usually" because not everyone accepts this. My view is that Dworkin rejects this position. This by itself is a significant aspect of his work, that is very relevant to understanding his jurisprudence, but not one I can consider here.
} 


\section{Appendix (taken from "The Place of Legitimacy in Legal Theory")}

Legal positivists think of jurisprudence in the following way:

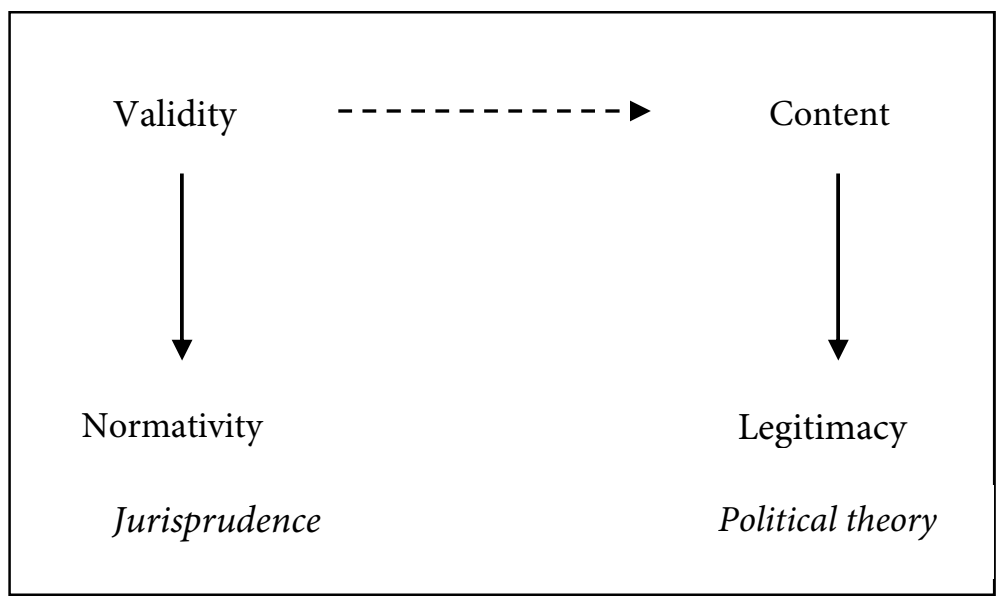

They also think that all legal philosphers share this picture, and that therefore the disagreement between legal positivists and anti-positivists is about the right way of understanding the conditions of legal validity. But this is a mistake, both as a matter of describing others' views, and as a matter of philosophy. I believe, for example, that Dworkin arranges these concepts in the following way:

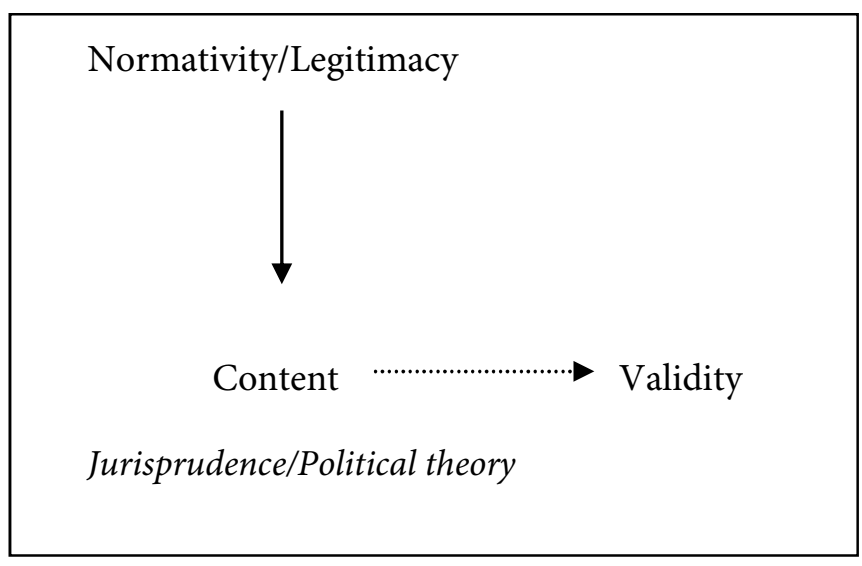

This is not the only possible arrangement of these concepts, but it is clear (to me) that the approach of contemporary positivists (but not of Hobbes or Bentham), that puts validity in the center, and in this way separates legal philosophy from political philosophy, is mistaken. 